\title{
ZBRODNIA WYSTAWIANIA PUSTYCH FAKTUR W VAT
}

Streszczenie. Tematem artykułu jest proceder wystawiania tzw. pustych faktur, a przede wszystkim wyjaśnienie, co należy rozumieć pod tym pojęciem w orzecznictwie sądów polskich oraz Trybunału Sprawiedliwości. Ponadto przedmiotem rozważań objęte zostały skutki podatkowe dotyczące możliwości odliczenia kwoty wskazanej na fakturze przez otrzymującego fakturę oraz wynikające z art. 108 ustawy o podatku od towarów i usług dla wystawiającego fakturę. Ponieważ kwalifikacja prawna tych zdarzeń nie jest jednolicie ujmowana w orzecznictwie sądowym oraz w doktrynie, niezbędne stało się także przedstawienie poglądów w tym zakresie.

Słowa kluczowe: podatek od wartości dodanej (VAT), podatek naliczony (od zakupu), podatek należny (od sprzedaży), pusta faktura.

\section{WSTĘP}

Wystawianie tzw. pustych faktur ${ }^{1}$, dotyczących zbycia towarów, stało się jednym z najważniejszych zagadnień w teorii oraz praktyce organów prowadzących oraz nadzorujących postępowania karnoskarbowe oraz postępowania karne, których przedmiotem jest funkcjonowanie tzw. karuzel podatkowych ${ }^{2}$ i narażanie Skarbu Państwa na uszczuplenie należności publicznoprawnych.

Stąd podjęte działania wprowadzenia zmian w prawie karnym materialnym, polegające na dodaniu art. 270a, art. 271a, art. 277a do 277d do ustawy z dnia 6 czerwca 1997 r. - Kodeks karny (Dz.U. z 1997 r. Nr 88, poz. 553 ze zm.; dalej: k.k.) na podstawie ustawy z dnia 10 lutego 2017 r. o zmianie ustawy - Kodeks karny oraz niektórych innych ustaw (Dz.U. z 2017 r., poz. 244), a dotyczące uznania za zbrodnię podrabiania, przerabiania, wystawiania oraz używania jako autentyczne pustych faktur.

Ustawodawca, wprowadzając kryminalizację pustych faktur, zdawał sobie sprawę z tego, że są one narzędziem do popełniania przestępstw polegających na uszczupleniach podatkowych. Dlatego uznał za potrzebne zagrożenie karą

*Prokurator Prokuratury Regionalnej w Łodzi, kalifornia1@wp.pl.

${ }^{1}$ Termin ,puste faktury” nie jest terminem języka prawnego, lecz przyjął się w języku prawniczym, także w orzecznictwie sądowym.

${ }^{2}$ Termin „karuzela podatkowa” oznacza cyrkulację narzędzi, jakimi są faktury, które są przekazywane kolejno i przetwarzane przez kolejnych sprawców w odrębnych podmiotach gospodarczych. 
przekraczającą dolną granicę pozbawienia wolności, co czyni zachowania opisane $\mathrm{w}$ art. $270 \mathrm{a} \S 2$, art. 271a $\S 2$ k.k. zbrodnią, a wskazane w art. 277a $\S 1$ k.k. zagrożone karą pozbawienia wolności na czas nie krótszy niż 5 lat albo karą 25 lat pozbawienia wolności. Jest to koncepcja karania na przedpolu zjawiska przestępczego uzyskania należności publicznoprawnych przez innych sprawców.

\section{KONSTRUKCJA PODATKU OD TOWARÓW I USEUG}

Ustawa z dnia 11 marca 2004 r. o podatku od towarów i usług (tekst jedn. Dz.U. z 2017 r. poz. 1221 ze zm.; dalej: u.p.t.u.) już w art. 1.1. wskazuje, że reguluje opodatkowanie podatkiem od towarów i usług.

Podatnikiem podatku od towarów i usług, zgodnie z art. 15.1. wskazanej ustawy, są osoby prawne, jednostki organizacyjne niemające osobowości prawnej oraz osoby fizyczne, wykonujące samodzielnie działalność gospodarczą, bez względu na cel lub rezultat takiej działalności. Opodatkowaniu, zgodnie z art. 5.1. u.p.t.u., podatkiem od towarów i usług podlegają:

1) odpłatna dostawa towarów i odpłatne świadczenie usług na terytorium kraju;

2) eksport towarów;

3) import towarów na terytorium kraju;

4) wewnątrzwspólnotowe nabycie towarów za wynagrodzeniem na terytorium kraju;

5) wewnątrzwspólnotowa dostawa towarów.

Wskazane wyżej czynności podlegają opodatkowaniu niezależnie od tego, czy zostały wykonane z zachowaniem warunków i form określonych przepisami prawa, na co wskazuje art. 5 ust. 2 ustawy.

Zgodnie $\mathrm{z}$ art. 86 ust. 1 u.p.t.u., w zakresie, w jakim towary i usługi są wykorzystywane do wykonywania czynności opodatkowanych, podatnikowi, o którym mowa w art. 15, przysługuje prawo do obniżenia kwoty podatku należnego o kwotę podatku naliczonego z zastrzeżeniem art. 114, art. 119 ust. 4, art. 120 ust. 17 i 19 oraz art. 124.

Podatnik dokonujący obrotu towarem jest zobowiązany do wystawienia faktury, która dokumentuje sprzedaż, a także dostawę towarów i świadczenie usług na rzecz innego podatnika, podatku od wartości dodanej lub podatku o podobnym charakterze, lub na rzecz osoby prawnej niebędącej podatnikiem, a także innych czynności, co wynika wprost z treści art. 106b ust. 1 ustawy.

W praktyce podmioty wystawiają faktury, które rzekomo mają dokumentować obrót towarem oraz świadczenie usług. Zdarzenia gospodarcze opisane w takich fakturach nie mają miejsca, przy czym podana w fakturach nieprawda może mieć różny zakres. Po pierwsze, cały obrót towarem, jaki został wykazany może w ogóle nie mieć miejsca. Możliwe są również i takie przypadki, kiedy tylko w części obrót wykazany na fakturze nie miał miejsca lub 
wystawca faktury nie jest w rzeczywistości tym podmiotem, który dokonuje zbycia towaru na rzecz nabywcy lub świadczenia usługi. Powstaje pytanie o powód takich czynności i skutki prawne, które z nich wynikają, co łączy się z pojęciem pustych faktur i określonych przepisami oraz orzecznictwem sądowym skutkami dla podmiotu wystawiającego takie dokumenty, a ponadto dla podmiotu, który otrzymuje te faktury, co jest przedmiotem dalszych rozważań.

\section{POJĘCIE PUSTYCH FAKTUR W ORZECZNICTWIE SĄDOWNICTWA ADMINISTRACYJNEGO}

Problematyka wystawiania pustych faktur dotyka podatku od towarów i usług, co wynika przede wszystkim z konstrukcji tego podatku i metody jego obliczania. Ogólnie polega on na odliczeniu od podatku należnego, czyli od sprzedaży, kwoty podatku naliczonego, czyli od zakupu. Zobowiązanie podatkowe w podatku od towarów i usług powstaje tylko wtedy, gdy wartość podatku należnego w danym miesiącu jest wyższa od wartości podatku naliczonego (Oczkowski 2009, 83). Ustawodawca, chcąc ograniczyć wystawianie pustych faktur, wprowadził do ustawy o podatku od towarów i usług art. 108, który w ust. 1 stanowi, że w przypadku, gdy osoba prawna, jednostka organizacyjna niemająca osobowości prawnej lub osoba fizyczna wystawi fakturę, w której wykaże kwotę podatku, jest obowiązana do jego zapłaty ${ }^{3}$. Na podstawie tego przepisu wykształciło się bogate orzecznictwo sądowe, w którym wskazane zostały przesłanki uznania faktury za „pustą”. Pojęcie pustej faktury zostało wyjaśnione między innymi w wyroku Naczelnego Sądu Administracyjnego z dnia 26 listopada 2014 r. (I FSK 1537/13, LEX nr 1658030), który stwierdził, po pierwsze, że faktura może być nierzetelna $z$ tego powodu, że czynność nią udokumentowana została dokonana, ale nie przez wystawcę na tej fakturze uwidocznionego, po drugie, faktura może nie dokumentować czynności rzeczywiście dokonanej ze względu na jej przedmiot, tzn. może dokumentować nie taką dostawę towarów lub świadczenie usług, jakie były przedmiotem rzeczywistej transakcji, i po trzecie, faktura może być również wystawiona w celu stwierdzenia transakcji w ogóle niedokonanej i będzie to tzw. pusta faktura. Podobne stanowisko zajął Wojewódzki Sąd Administracyjny we Wrocławiu w wyroku z dnia 25 kwietnia 2017 r. (I SA/Wr 1373/16,

${ }^{3}$ W wyr. z dnia 31 maja 2017 r., I FSK 1824/15, Naczelny Sąd Administracyjny (dalej: NSA) w Warszawie uznał, że przepis art. 108 ust. 1 u.p.t.u. daje podstawę do wywodzenia obowiązku zapłaty podatku tylko na tej podstawie, że wystawiona została faktura (w tym tzw. pusta faktura) i że jest przepisem o charakterze prewencyjnym, mającym przeciwdziałać wprowadzeniu do obiegu nierzetelnych faktur, z których nieuczciwi przedsiębiorcy mogli wywodzić prawo do odliczenia (LEX nr 2314508). 
LEX nr 2315820), w którym stwierdził, że tzw. puste faktury to zarówno faktury, które nie dokumentują żadnej czynności, jak i takie, które służą ukryciu faktycznego dostawcy towaru.

\section{POJĘCIE PUSTYCH FAKTUR W ORZECZNICTWIE TRYBUNALU SPRAWIEDLIWOŚCI UNII EUROPEJSKIEJ}

Problematyka pustych faktur dotyka nie tylko Polski, ale także innych krajów, w których również wprowadzony został podatek od towarów i usług. Zgodnie z art. 5-7 Szóstej dyrektywy Rady z dnia 17 maja 1977 r. w sprawie harmonizacji ustawodawstwa Państw Członkowskich w odniesieniu do podatków obrotowych - wspólny system podatku od wartości dodanej: ujednolicenia podstaw wymiary podatku (77/388/EWG; Dz.Urz. UE L z 1977 r. Nr 145.1; dalej: Szósta dyrektywa), opodatkowaniu podlegały: dostawa towaru, świadczenie usług oraz przywóz towaru. Na podstawie art. 17 tejże dyrektywy prawo do odliczenia powstaje w momencie, w którym odliczany podatek staje się wymagalny. Ponadto podatnik jest uprawniony do odliczenia od podatku, który zobowiązany jest zapłacić, o ile towary i usługi są używane do celów zawieranych transakcji.

W wyroku z dnia 13 grudnia 1989 r. (C-342/87, LEX nr 84293) Trybunał Sprawiedliwości Unii Europejskiej stwierdził, że prawa do odliczenia podatku VAT przewidzianego w Szóstej dyrektywie z tytułu dostaw towarów lub świadczenia usług przez innego podatnika nie dotyczy podatku, który na mocy artykułu 21(1)(c) dyrektywy jest należny wyłącznie z tego względu, iż został wykazany na fakturze.

Szósta dyrektywa Rady z dnia 17 maja 1977 r. została zastąpiona Dyrektywą 2006/112/WE Rady z dnia 28 listopada 2006 r. w sprawie wspólnego systemu podatku od wartości dodanej (Dz.Urz. UE L z 2006 r. Nr 347/1; dalej: Dyrektywa 2006/112), w której na podstawie art. 2 przyjęto, że opodatkowaniu VAT podlegają: odpłatna dostawa towarów na terytorium państwa członkowskiego przez podatnika działającego $\mathrm{w}$ takim charakterze, odpłatne wewnątrzwspólnotowe nabycie towarów na terytorium państwa członkowskiego, odpłatne świadczenie usług na terytorium państwa członkowskiego przez podatnika działającego w takim charakterze oraz import towarów.

Orzecznictwo Trybunału Sprawiedliwości Unii Europejskiej stoi na stanowisku, że należy odmówić prawa do odliczenia podatku VAT, gdy podatnik może podejrzewać nieprawidłowości lub naruszenie prawa. Dotyczy to w szczególności podatku naliczonego w fakturach, w których podany jest nieprawdziwy wystawca lub nie dokumentują one rzeczywistej czynności ze względu na jej przedmiot. W wyroku z dnia 21 czerwca 2012 r. (C-80/11, LEX nr 1165797) Trybunał Sprawiedliwości Unii Europejskiej wskazał, że jeżeli podatnik nie miał przesłanek 
podejrzewać, że wystawca faktury dopuścił się nieprawidłowości lub przestępstwa, to brak jest podstaw do odmowy prawa do odliczenia $z$ tego powodu, iż podatnik nie upewnił się, że wystawca faktury jest podatnikiem, że dysponował on tymi towarami i był w stanie je dostarczyć oraz że wywiązał się z obowiązku złożenia deklaracji i zapłaty podatku od wartości dodanej, albo z tego powodu, że podatnik posiadał tylko fakturę.

\section{SKUTKI W PRAWIE PODATKOWYM WYSTAWIANIA PUSTYCH FAKTUR W ORZECZNICTWIE SĄDÓW POLSKICH}

Trzeba stwierdzić, że zgodnie z orzecznictwem sądowym wystawianie pustych faktur wywołuje dwojakie skutki prawne. Po pierwsze, pusta faktura nie daje prawa temu, kto otrzymał fakturę do odliczenia wykazanego w niej podatku. Stanowisko takie wynika z jednolitego orzecznictwa sądownictwa administracyjnego. Przykładem może być wyrok Naczelnego Sądu Administracyjnego w Warszawie z dnia 27 września 2011 r. (I FSK 1403/10, LEX nr 1068161), z którego wynika, iż faktura nieodzwierciedlająca rzeczywiście dokonanej przez jej wystawcę czynności, która rodziłaby u niego obowiązek podatkowy, nie daje odbiorcy tej faktury prawa do odliczenia wykazanego w niej podatku.

Stanowisko to znajduje także poparcie w doktrynie, gdzie jest reprezentowany tożsamy pogląd, z którego wynika, że dysponowanie fakturą stanowi jedynie formalny warunek skorzystania z uprawnienia do odliczenia podatku VAT i konieczne jest rzeczywiste wykonanie czynności, która rodzi u wystawcy faktury obowiązek podatkowy z tytułu realizacji czynności na rzecz nabywcy (Hermann, Sykuna 2016, 301).

Trzeba zastrzec, iż w procesie dotyczącym narażenia Skarbu Państwa na uszczuplenie należności publicznoprawnej występują czynności - w ramach struktury karuzeli podatkowej, które mają znaczenie dla tzw. karuzeli VAT jako całości. W tym zakresie wydane zostało istotne orzeczenie przez Wojewódzki Sąd Administracyjny w Bydgoszczy z dnia 6 czerwca 2011 r., w którym stwierdzono, że ,[n] ie rodzą skutku podatkowego polegającego na prawie do obniżenia, te czynności, które zaistnieją w ramach organizacji całego przedsięwzięcia ukierunkowanego na oszustwo podatkowe występujące na jednym z jego etapów" (I SA/Bd 118/11, LEX nr 990375). Sąd orzekł ponadto, że fakt świadomego uczestniczenia w oszukańczej karuzeli podatkowej dawał prawo do pozbawienia obniżenia podatku i żądania prawidłowego rozliczenie podatku należnego. Ponadto podatnik, wystawiając faktury, wykreował obowiązek podatkowy, o jakim mowa w art. 108 u.p.t.u.

Tutaj dochodzimy do drugiego skutku, który wynika z treści tego artykułu dla podmiotu, który taką fakturę wystawił, czyli zapłaty podatku wykazanego 
na fakturze przez jej wystawcę ${ }^{4}$ W orzecznictwie polskich sądów reprezentowany jest pogląd, wedle którego samo wystawienie pustej faktury, która nie dokumentuje rzeczywistych zdarzeń, rodzi obowiązek zapłaty podatku VAT wskazanego w pustej fakturze ${ }^{5}$. Obowiązek ten istnieje niezależnie od rozmiarów i konsekwencji podatkowych obrotu ${ }^{6}$. Problematyczne staje się wskazanie, czy sankcja, jaka została przewidziana w art. 108 u.p.t.u. może być uznana za podatek czy też sankcję quasi-podatkową. W wielu orzeczeniach sąd stoi na stanowisku, iż przepis tego artykułu wprowadził specyficzną instytucję obowiązku zapłaty podatku, wykazanego w fakturze. Sądy przyjmują, że z wykładni gramatycznej art. 108 u.p.t.u. wynika, iż zobowiązanie do zapłaty wskazanej na fakturze kwoty powstaje $\mathrm{z}$ mocy prawa, w dacie, w której dany podmiot wprowadza do obrotu taką fakturę. Zobowiązanie wynika bezpośrednio z wykazania podatku na faktu$\mathrm{rze}^{7}$. Tak więc każdy podmiot, który wprowadził do obrotu fakturę z wykazaną w niej kwotą podatku VAT, ma obowiązek zapłaty wykazanego podatku, przy czym obowiązek ten przyjmuje postać swoistej sankcji ${ }^{8}$. Należy także zaznaczyć, że z części orzecznictwa sądowego jasno wynika, że na podstawie wskazanego artykułu nie można mówić o podatku z tytułu czynności podlegających opodatkowaniu. Podatek od towarów i usług wymierzany jest w związku z obrotem, a jeżeli go brak, to nie ma podstaw do powstania obowiązku podatkowego. W wyroku z dnia 4 grudnia 2009 r. Naczelny Sąd Administracyjny w Warszawie stwierdził wręcz, że

mimo użycia w tym przepisie sformułowania „kwota podatku” to tak naprawdę nie mamy do czynienia z podatkiem od towarów i usług. Ten ostatni bowiem wynika bezpośrednio z zaistnienia czynności podlegającej opodatkowaniu, które to zostały wymienione w art. 5 ustawy o podatku od towarów i usług z 2004 r. (wyr. NSA z dnia 4 grudnia 2009 r., I FSK 1859/08, LEX nr 615971).

\section{Sąd dalej uzasadnia, iż}

${ }^{4}$ W wyr. z dnia 19 stycznia 2017 r., III SA/Wa 3318/15, Wojewódzki Sąd Administracyjny (dalej: WSA) w Warszawie stwierdził, że przepis art. 108 ust. 1 u.p.t.u. kreuje obowiązek zapłaty VAT wykazanego na fakturze w oderwaniu od regulacji dotyczących obowiązku podatkowego i zobowiązania podatkowego. Zapłata podatku VAT wykazanego w deklaracji VAT-7, w której ujęto podatek z tzw. pustej faktury, pozostaje bez wpływu na obowiązek jego zapłaty na podstawie art. 108 ust. 1 u.p.t.u. (LEX nr 2267959).

${ }^{5}$ Wyr. WSA we Wrocławiu z dnia 26 sierpnia 2008 r., I SA/Wr 143/08, LEX nr 485315; tak samo wyr. NSA w Warszawie z dnia 30 lipca 2009 r., I FSK 866/08, LEX nr 552188; tak samo wyr. WSA w Warszawie z dnia 10 maja 2010 r., III SA/Wa 384/10, LEX nr 603708.

${ }^{6}$ Wyr. NSA w Warszawie z dnia 2 października 2012 r., I FSK 2017/11, LEX nr 1233050 oraz wyr. WSA w Gliwicach z dnia 11 czerwca 2014 r,. III SA/Gl 70/14, LEX nr 150830.

${ }^{7}$ Wyr. WSA we Wrocławiu z dnia 25 kwietnia 2017 r., I SA/Wr 1373/16, LEX nr 2315820.

${ }^{8}$ Wyr. NSA w Warszawie z dnia 30 lipca 2009 r., I FSK 866/08, LEX nr 552188; wyr. WSA w Warszawie z dnia 10 maja 2010 r., III SA/Wa 384/10, LEX nr 603708; wyr. WSA w Bydgoszczy z dnia 6 czerwca 2011 r., I SA/Bd 118/11, LEX nr 990375; wyr. WSA w Bydgoszczy z dnia 11 lipca 2017 r., I SA/Bd 444/17, LEX nr 2326299. 
obowiązek zapłaty wynikający z art. 108 ust. 1 nie może być również w żaden sposób wiązany z powstaniem obowiązku podatkowego, którego to moment powstania, zgodnie z art. 19 ust. 1 ustawy o VAT z 2004 r. łączy się z chwilą wydania towaru lub wykonania usługi lub jak w przypadku czynności potwierdzonej fakturą (art. 19 ust. 4 ustawy o VAT z 2004 r.) z chwilą wystawienia faktury, nie później niż w siódmym dniu, licząc od dnia wydania towaru lub wykonania usługi (I FSK 1859/08).

W piśmiennictwie Jerzy Duży przekonuje, że w przypadku art. 108 ustawy o VAT mamy do czynienia z sankcją quasi-podatkową, która nie jest sama w sobie podatkiem (Duży 2013, 176-182). Podobne stanowisko zajmuje Paweł Kołodziejski, który twierdzi, że kwota wskazana w decyzji podatkowej, wydanej na podstawie art. 108 u.p.t.u., nie może być utożsamiana z uszczupleniem podatku w rozumieniu Kodeksu karnego skarbowego (Kołodziejski 2015, 85-105). Stanowisko, że art. 108 u.p.t.u. dotyczy sankcji quasi-podatkowych, ma istotne konsekwencje w prawie karnym materialnym, ponieważ przy jego przyjęciu powstają zasadnicze wątpliwości o dokonanie kwalifikacji kwoty wyliczonej na podstawie tego artykułu, a nieodprowadzonej do Skarbu Państwa, jako narażającej Skarb Państwa na uszczuplenie, które realizuje znamiona czynów zabronionych, opisanych w Kodeksie karnym skarbowym. Dalszą konsekwencją tejże koncepcji jest przyjęcie, iż brak jest podstaw do dokonania kwalifikacji zachowania polegającego na wystawianiu pustych faktur na podstawie przepisów Kodeksu karnego, przynajmniej do czasu wprowadzenia art. 270a oraz art. 271a k.k., bowiem i tak fikcyjny obrót nie ma znaczenia dla wymiaru podatku VAT. Wątpliwe pozostaje zakwalifikowanie wystawiania tzw. pustych faktur na podstawie art. $62 \S 2$ Kodeksu karnego skarbowego (Dz.U. z 2017 r., poz. 2226 ze zm.; dalej: k.k.s.), skoro zachowanie, polegające na wystawieniu takiej faktury, nie narusza obowiązków podatkowych.

\section{SKUTKI W PRAWIE PODATKOWYM WYSTAWIANIA PUSTYCH FAKTUR W ORZECZNICTWIE TRYBUNAŁU SPRAWIEDLIWOŚCI}

Gdy dokonujemy analizy orzecznictwa Trybunału Sprawiedliwości Unii Europejskiej, trzeba stwierdzić, że w głównych zrębach jest ono zbliżone do orzecznictwa sądów polskich, choć w wielu przypadkach wydaje się być bardziej korzystne dla podmiotu, który otrzymał odmowę odliczenia podatku wskazanego w pustej fakturze.

W wyroku z dnia 13 grudnia 1989 r. Trybunał Sprawiedliwości Unii Europejskiej stwierdził, że prawo do odliczenia podatku VAT, przewidziane w Szóstej dyrektywie z tytułu dostaw towarów lub świadczenia usług przez innego podatnika, przysługuje wyłącznie w odniesieniu do podatków faktycznie należnych, tj. podatków przypadających do zapłaty z tytułu działalności podlegającej opodatkowaniu lub zapłaconych, o ile były one należne. Zasada ta nie dotyczy 
podatku, który na mocy artykułu 21(1)(c) dyrektywy jest należny wyłącznie z tego względu, iż został wykazany na fakturze (C-342/87, LEX nr 84293). W orzecznictwie sądowym Trybunału Sprawiedliwości Unii Europejskiej zwraca się uwagę na świadomość co do wystawienia pustej faktury. Przykładem może być wyrok Trybunału Sprawiedliwości Unii Europejskiej z dnia 21 czerwca 2012 r. (C-80/11, LEX nr 1165797), w którym sąd uznał, że przepisy art. 167, art. 168 lit. a), art. 178 lit. a), art. 220 pkt 1 i art. 226 Dyrektywy 2006/112 w sprawie wspólnego systemu podatku od wartości dodanej należy interpretować w ten sposób, że stoją one na przeszkodzie praktyce krajowej, w ramach której organ podatkowy odmawia podatnikowi prawa do odliczenia od kwoty należnego podatku od wartości dodanej kwoty tego podatku należnego lub zapłaconego z tytułu świadczonych mu usług $z$ tego powodu, iż wystawca faktur dotyczących owych usług lub jeden z jego usługodawców dopuścił się nieprawidłowości, bez udowodnienia przez organ podatkowy na podstawie obiektywnych przesłanek, iż podatnik wiedział lub powinien był wiedzieć, że transakcja mająca stanowić podstawę prawa do odliczenia wiązała się z przestępstwem popełnionym przez wystawcę faktury lub inny podmiot działający na wcześniejszym etapie obrotu. Trybunał dalej wskazał, że nie można odmówić prawa do odliczenia podatku na tej podstawie, iż podatnik nie upewnił się, że wystawca faktury jest podatnikiem, że dysponował on tymi towarami i był w stanie je dostarczyć oraz że wywiązał się z obowiązku złożenia deklaracji i zapłaty podatku od wartości dodanej, albo z tego powodu, że podatnik nie posiada poza fakturą innych dokumentów potwierdzających spełnienie powyższych warunków (C-80/11). Zdaniem Trybunału Sprawiedliwości Unii Europejskiej tylko wówczas, gdy istnieją przesłanki, by podejrzewać nieprawidłowości lub naruszenie prawa, przezorny przedsiębiorca powinien, zależnie od okoliczności konkretnego przypadku, zasięgnąć informacji na temat podmiotu, u którego zamierza nabyć towary lub usługi, w celu upewnienia się co do jego wiarygodności (C-80/11). Ponadto, na podstawie wyroku Trybunału Sprawiedliwości Unii Europejskiej z dnia 6 grudnia 2012 r. (C-285/11, LEX nr 1229752), jako niezgodne z zasadami funkcjonowania prawa do odliczenia jest sankcjonowanie odmową możliwości skorzystania $\mathrm{z}$ tego prawa podatnika, który nie wiedział i nie mógł wiedzieć, że w ramach danej transakcji dostawca dopuścił się przestępstwa lub że inna transakcja $\mathrm{w}$ łańcuchu dostaw, dokonana przed transakcją przeprowadzoną przez owego podatnika lub po niej, została dokonana z naruszeniem przepisów o podatku od wartości dodanej. Wprowadzenie systemu odpowiedzialności bez winy wykraczałoby bowiem poza zakres niezbędny do ochrony interesów Skarbu Państwa9. Podobny pogląd został wyrażony w wyroku Trybunału Sprawiedliwości Unii Europejskiej z dnia 13 lutego 2014 r. (C-18/13, LEX nr 1424765), w którym uznano, że Dyrektywę 2006/112 w sprawie wspólnego systemu podatku

${ }^{9}$ Podobnie wyr. Trybunału Sprawiedliwości Unii Europejskiej (dalej: TSUE) z dnia 6 lipca 2006 r., C-439/04, zob. http://www.eur-lex.europa.eu [dostęp 3.06.2018]. 
od wartości dodanej należy interpretować w ten sposób, iż sprzeciwia się ona, aby podatnik dokonywał odliczenia podatku od wartości dodanej, znajdującego się na fakturach wystawionych przez dostawcę, jeżeli, pomimo że usługa została wyświadczona, okazuje się, iż nie została ona w rzeczywistości wykonana przez danego usługodawcę lub przez jego podwykonawcę, o ile spełnione zostały dwa warunki: okoliczności te stanowią oszukańcze zachowanie i wykazano na podstawie obiektywnych dowodów przedstawionych przez organy podatkowe, że podatnik wiedział lub powinien wiedzieć, iż transakcja przywoływana w celu uzasadnienia prawa do odliczenia związana była z tym oszustwem (C-18/13). W powołanym orzeczeniu Trybunał wskazał, że każdy podatnik powinien prowadzić rachunkowość w sposób wystarczająco szczegółowy, aby umożliwić zastosowanie podatku VAT oraz jego kontrolę przez organ podatkowy, a uchybienie przez usługodawcę niektórym wymogom o charakterze księgowym nie może podważać prawa do odliczenia podatku przysługującego usługobiorcy w zakresie naliczonego i zapłaconego podatku VAT, jeżeli faktury dotyczące wyświadczonych usług zawierają wszystkie informacje wymagane przez art. 226 Dyrektywy 2006/112 (C-18/13). Z wyroku Trybunału Sprawiedliwości Unii Europejskiej z dnia 22 października 2015 r. (C-277/14, LEX nr 1814891) wynika, że przepisy Szóstej dyrektywy 77/388 w sprawie harmonizacji ustawodawstw państw członkowskich w odniesieniu do podatków obrotowych, zmienionej dyrektywą 2002/38, należy interpretować w ten sposób, iż sprzeciwiają się one przepisom krajowym, które odmawiają podatnikowi prawa do odliczenia podatku od wartości dodanej należnego lub zapłaconego od dostarczonych mu towarów z uwagi na to, że faktura została wystawiona przez podmiot, który w świetle kryteriów przewidzianych przez te przepisy należy uważać za podmiot nieistniejący i nie ma możliwości ustalenia tożsamości rzeczywistego dostawcy towarów, chyba że zostanie wykazane, iż ów podatnik wiedział lub powinien był wiedzieć, że rzeczona dostawa wiązała się z przestępstwem w zakresie podatku od wartości dodanej.

Jeżeli chodzi o skutki podatkowe związane $\mathrm{z}$ wystawieniem pustych faktur w ramach tzw. obrotu karuzelowego, to w wyroku z dnia 6 lipca 2006 r. w sprawach połączonych (C-439/04 Axel Kittel v. Państwo Belgijskie oraz C-440/04 Państwo Belgijskie v. Recolta Recycling SPRL ${ }^{10}$ Trybunał Sprawiedliwości Unii Europejskiej wskazał, iż podatnikami, uczestniczącymi w tzw. transakcji karuzelowej, którzy będą mogli skorzystać z prawa do odliczenia, będą podmioty gospodarcze podejmujące wszelkie możliwe działania, których podjęcia można się od nich w sposób uzasadniony domagać w celu zapewnienia, że realizowane przez nie transakcje nie stanowią części łańcucha obejmującego transakcję dotkniętą oszustwem w podatku VAT.

Analiza orzecznictwa Trybunału Sprawiedliwości Unii Europejskiej jasno pokazuje, że nie jest możliwe mechaniczne uznanie, iż podatnik nie ma prawa

${ }^{10}$ Zob. http://www.eur-lex.europa.eu [dostęp 3.06.2018]. 
do odliczenia podatku VAT. Sam brak podmiotu wskazanego na fakturze nie świadczy o świadomości podatnika uczestniczenia w oszustwie. Konieczne jest wykazanie wiedzy lub co najmniej - na podstawie szeregu okoliczności - podejrzenia, że podmiot może uczestniczyć w oszustwie. Z dużą ostrożnością nakładane są pewne obowiązki weryfikacyjne na podatnika, mające na celu dokonanie przez niego sprawdzeń. Trzeba mieć na uwadze to, że podatnik ma bardzo ograniczony zasób narzędzi do takich czynności i nie jest głównym zadaniem podatnika, a odpowiednich organów, ustalanie, czy dany podmiot wystawia puste faktury i czy jest znikającym podatnikiem.

Przechodząc do drugiego skutku wystawienia pustej faktury, trzeba wskazać, że zgodnie z art. 21 pkt 1 lit. c) Szóstej dyrektywy, poprzedniczki Dyrektywy nr 2006/112/WE Rady Unii Europejskiej z dnia 28 listopada 2006 r., zobowiązaną do zapłaty podatku od wartości dodanej była każda osoba wykazująca podatek od wartości dodanej na fakturze lub innym dokumencie uznawanym za fakturę. Jeszcze w orzecznictwie Trybunału Sprawiedliwości Unii Europejskiej na podstawie Szóstej dyrektywy z dnia 17 maja 1977 r. przyjęto, że wystawienie tzw. pustej faktury rodzi obowiązek zapłaty wykazanej w niej kwoty podatku. Tak też orzekł Trybunał Sprawiedliwości Unii Europejskiej w wyroku z dnia 13 grudnia 1989 r. (C-342/87, LEX nr 84293), w którym wskazał, że podatek VAT, na mocy artykułu 21(1)(c) dyrektywy, jest należny wyłącznie z tego względu, iż został wykazany na fakturze. Nieco inaczej orzekł Trybunał Sprawiedliwości Unii Europejskiej w wyroku z dnia 6 listopada 2003 r. (C-78/02, LEX nr 174079), w którym wskazał, że nie jest wykluczone prawo zwrotu omyłkowo wskazanej na fakturze kwoty podatku od wartości dodanej, gdy sporne usługi nie podlegają opodatkowaniu podatkiem od wartości dodanej, a kwota wykazana na fakturze nie może być zakwalifikowana jako podatek od wartości dodanej.

Obecnie odpowiednikiem art. 108 ustawy o podatku od towarów i usług jest art. 203 Dyrektywy nr 2006/112, zgodnie z którym samo wystawienie kwoty podatku na fakturze zobowiązuje do jego odprowadzenia do właściwego organu. $\mathrm{Z}$ treści tego przepisu jednoznacznie wynika, że ,[k]ażda osoba, która wykazuje VAT na fakturze, jest zobowiązana do zapłaty VAT" (Dz.Urz. UE L z 2006 r. $\mathrm{Nr} 347 / 1)$. Na podstawie tego przepisu orzecznictwo sądowe również stoi na stanowisku, że wskazanie kwoty podatku na fakturze zobowiązuje do jego odprowadzenia. Przykładowo w wyroku z dnia 31 stycznia 2013 r. Trybunał Sprawiedliwości Unii Europejskiej stwierdził, że

[a]rtykuł 203 dyrektywy 2006/112 w sprawie wspólnego systemu podatku od wartości dodanej należy interpretować w ten sposób, że podatek od wartości dodanej wyszczególniony przez podmiot na fakturze jest należny od tego podmiotu niezależnie od tego, czy transakcja opodatkowana rzeczywiście miała miejsce (C-642/11, LEX nr 1258555) ${ }^{11}$.

${ }^{11}$ Podobnie wyr. TSUE z dnia 18 czerwca 2009 r., C-566/07, LEX nr 498853, w którym trybunał wskazał, że podatek VAT wykazany na fakturze jest należny niezależnie od jakiegokolwiek 


\section{KWALIFIKACJA PRAWNA WYSTAWIANIA PUSTYCH FAKTUR}

Podstawowym przepisem przy dokonywaniu kwalifikacji prawnej pustych faktur jest art. 8 Kodeksu karnego skarbowego, z którego wynika, że jeżeli jeden czyn wypełnia znamiona przestępstwa skarbowego lub wykroczenia skarbowego oraz przestępstwa lub wykroczenia, określone w przepisach karnych innej ustawy, to stosuje się każdy z tych przepisów.

Oznacza to, że konieczne jest uwzględnienie kwalifikacji prawnej z Kodeksu karnego skarbowego oraz innych aktów prawnych, głównie Kodeksu karnego. W zakresie tego przepisu istotne jest rozstrzygnięcie podjęte $\mathrm{w}$ formie uchwały siedmiu sędziów Sądu Najwyższego z dnia 24 stycznia 2013 r., kiedy to sąd wskazał, że reguły wyłączania wielości ocen mają zastosowanie jedynie w wypadku zbiegu przepisów ustawy, a nie stosuje się ich w razie idealnego zbiegu czynów zabronionych, o którym mowa w art. $8 \S 1$ k.k.s. (I KZP 19/12, LEX nr 1252697). Trzeba stwierdzić, że ta uchwała spotkała się w doktrynie z krytyką, z której wynika, że sąd, odrzucając reguły wyłączania wielości ocen, przy uwzględnieniu wszystkich konkurujących ze sobą przepisów, może doprowadzić do zafałszowania podstawy kwalifikacji prawnej. Ponadto sąd chciał uzasadnić możliwość równoległego pociągnięcia do odpowiedzialności na podstawie Kodeksu karnego skarbowego oraz Kodeksu karnego, w szczególności sprawców, którzy wyłudzali zwrot podatku VAT, chodziło o to, aby zapobiec przedawnieniu karalności (Wilk 2013, 606; Kanarek 2013, 173-177; Duda 2013, 123-133).

Wystawianie pustych faktur nie jest jednolicie traktowane w orzecznictwie sądowym, gdzie można spotkać wiele orzeczeń odnoszących się do bardzo zbliżonych stanów faktycznych, a różnej kwalifikacji prawnej. Jak wskazał Sąd Najwyższy w wyroku z dnia 31 marca 2015 r., nie jest możliwe udzielenie jednej, uniwersalnej odpowiedzi na pytanie o kwalifikację prawną zdarzeń, polegających na wystawianiu pustych faktur (I KZP 28/14, OSNKW 2015, nr 5, poz. 40). Każda sprawa winna być rozpatrywana indywidualnie, co jednak nie usuwa głównych wątpliwości interpretacyjnych. Przed zmianami związanymi z wprowadzeniem art. 270a oraz art. 271a k.k. można wskazać na wielokierunkowość orzecznictwa sądowego dotyczącego kwalifikacji tych zdarzeń.

Pierwszy nurt opierał się na przyjęciu, iż wystawca pustej faktury wypełnia znamiona czynów zabronionych z art. 62 § 2 k.k.s. oraz art. 271 § 1 k.k. Sąd Najwyższy w orzeczeniu z dnia 15 listopada 2013 r. (II KK 295/13) przyjął, że konieczne jest przypisanie odpowiedzialności karnej z art. 62 § lub 5 k.k.s. oraz art. 271 $\S 1$ k.k. (post. SN z dnia 15 listopada 2013 r., II KK 295/13, LEX nr 1391781) ${ }^{12}$.

zobowiązania do jego zapłaty z tytułu transakcji podlegającej podatkowi VAT, a art. 21 ust. 1 lit. c) dyrektywy zmierza do eliminacji ryzyka utraty wpływów podatkowych, które może powodować prawo do odliczenia.

${ }^{12}$ Podobnie wyr. Sądu Apelacyjnego (dalej: SA) w Katowicach z dnia 16 stycznia 2014 r., II AKa 195/13, LEX nr 1422354; podobnie wyr. SA w Katowicach z dnia 8 sierpnia 2014 r., II AKa 200/14, LEX nr 1500762. 
Drugi kierunek orzecznictwa sądowego wywodził się z założenia, że decydujące znaczenie dla kwalifikacji prawnej czynów ma tzw. rodzajowy przedmiot ochrony, który przesądza o tym, że zachowanie polegające na wystawieniu pustej faktury winno być kwalifikowane tylko na podstawie art. $62 \S 2$ k.k.s. z uwagi na to, że wskazany artykuł umieszczony jest w rozdziale 6 , chroniącym między innymi obowiązek podatkowy. Przykładem orzeczenia w ramach tego nurtu może być wyrok Sądu Najwyższego z dnia 30 września 2003 r. (I KZP 22/03, OSNKW 2003, nr 9-10, poz. 75) $)^{13}$. Podobne stanowisko zajmuje tutaj Piotr Kardas, który uważa, że zakres zastosowania normy wywodzonej z art. $62 \S 2$ k.k.s. jest także bogatszy w treść i zarazem węższy zakresowo niż zakres zastosowania normy sankcjonującej, dekodowanej z art. 271 § 1 k.k., co umożliwia zastosowanie zasady lex specialis derogat legi generali, które prowadzi do tego, że wystawienie nierzetelnej faktury lub rachunku wypełnia znamiona zawarte w normie sankcjonującej z art. 62 § lub 5 k.k.s., a nie znajduje tu zastosowania norma sankcjonująca z art. 271 § 1 k.k. (Kardas 2007, 5-27; tak samo Ożóg 2017, 121).

Nie zawsze jednak tak jest, iż pusta faktura ma wpływ na wysokość podatku, ponieważ gdy obrót towarem w całości jest fikcyjny i nie służy celom podatkowym, a innym, związanym z wykazaniem obrotu dla celów oszukańczych, to wówczas wystawienie pustej faktury winno być kwalifikowane z art. 271 k.k., ewentualnie art. 286 k.k. Tutaj Sąd Apelacyjny w Katowicach w wyroku z dnia 25 maja 2012 r. (II AKa 97/12, LEX nr 1220220) wskazał, że jeżeli wystawienie nierzetelnej faktury nie godzi w obowiązek podatkowy, to nie można mówić o zaistnieniu czynu określonego w art. 62 § 2 k.k.s. Zbieżne stanowisko jest reprezentowane w doktrynie (Ożóg 2017, 121).

Reprezentowane są również poglądy, że jeżeli pusta faktura ma - choćby pośrednio - posłużyć do uzyskania zwrotu podatku VAT, to wówczas właściwa winna być kwalifikacja prawna z art. 76 k.k.s. Przykładem orzeczenia, w którym sąd orzekł, iż wykorzystanie pustej faktury do fikcyjnego wykazania transakcji handlowych, a następnie domaganie się zwrotu podatku VAT wypełnia znamiona czynu z art. 76 k.k.s., jest orzeczenie z dnia 12 sierpnia 2008 r. (wyr. SN z dnia 12 sierpnia 2008 r., V KK 76/08, LEX nr 449041), w którym sąd stwierdził, że porównanie treści art. 286 k.k. oraz art. 76 k.k.s. daje podstawy do przyjęcia, iż art. 76 k.k.s. jest lex specialis ${ }^{14}$. Stanowisko takie wynika także z poglądów doktryny, gdzie jako element przesądzający wskazany jest cel użycia fikcyjnej faktury (Kubacki, Bartosiewicz 2005, 475; Ożóg 2017, 121).

Jeżeli natomiast pusta faktura została sporządzona w innym celu niż podatkowy, to właściwe byłoby zastosowanie tylko odpowiedniego przepisu, który zawiera w swoich znamionach skutek, przykładowo art. 286 k.k. Orzeczenie w tym

${ }^{13}$ Tak samo wyr. Sądu Najwyższego (dalej: SN) z dnia 19 marca 2008 r., II KK 347/07, LEX nr 388503; tak samo wyr. SA w Szczecinie z dnia 12 maja 2016 r., II AKa 4/16, LEX nr 2093798.

${ }^{14}$ Podobnie wyr. SN z dnia 22 października 2009 r., IV KK 433/08, OSNwSK 2009, nr 1, poz. 2115. 
zakresie zostało wydane 1 marca 2004 r., w sprawie o sygn. akt VV KK 248/03, gdzie Sąd Najwyższy przyjął, iż podstawę prawnokarnej kwalifikacji zachowania polegającego na upozorowaniu przed organem skarbowym (przy pomocy fikcyjnych dokumentów lub przez podjęcie innych jeszcze czynności) przeprowadzenia realnej transakcji, w tym dotyczącej rzeczywiście istniejącego towaru, a nie jego substytutu, stanowi art. 286 k.k., a nie art. 76 k.k.s. ${ }^{15}$

Można także znaleźć orzeczenia, w których sąd przyjął możliwość zastosowania kwalifikacji prawnej z art. 76 k.k.s. oraz art. 286 k.k., argumentując, że reguły wyłączania wielości ocen nie mają zastosowania w razie idealnego zbiegu czynów zabronionych z art. $8 \S 1$ k.k.s. ${ }^{16}$ Jako uzasadnienie wskazany jest również brak podstaw do różnicowania, przy ocenie tylko przez pryzmat wykroczenia z Kodeksu karnego skarbowego, przedawnienia w porównaniu do ustalonego w Kodeksie karnym, a ponadto właściwości rzeczowej sądu ${ }^{17}$. Tak więc orzecznictwo sądowe nie jest jednolite, jeżeli chodzi o kwalifikowanie zachowań polegających na wystawianiu oraz wykorzystywaniu pustych faktur.

Tutaj jednak trzeba poczynić kilka uwag dotyczących czynów współukaranych uprzednich, kiedy pusta faktura jest narzędziem do tego, aby osiągnąć cel w postaci przykładowo nienależnego zwrotu podatku VAT, ale w ramach całej karuzeli VAT. Współukarane czynności uprzednie i następcze to takie formy zachowania przestępczego, za które sprawca nie podlega odrębnemu ukaraniu, jeżeli odpowiada za przestępstwo, które te formy zachowania się poprzedzają albo po którym następują. Dotyczy to przede wszystkim form stadialnych i zjawiskowych. Ponadto przestępstwo może być określone w ustawie w taki sposób, że obejmuje wytworzoną tym przestępstwem sytuację. Wówczas o bezkarności współukaranych czynności uprzednich lub następczych decyduje ten sam przedmiot zamachu (Andrejew 1970, 219-220; Marek 2006, 215-216). Posługując się tą argumentacją, należy stwierdzić, że przedmiotem zamachu w odniesieniu do czynu z art. 270 i 271 k.k. jest dokument (rozdział XXXIV Kodeksu karnego „Przestępstwa przeciwko wiarygodności dokumentów”), przedmiotem zamachu przy czynie z art. 286 k.k. jest mienie (rozdział XXXV Kodeksu karnego „Przestępstwa przeciwko mieniu”). Andrzej Marek wskazuje, że działania naruszające inne dobro prawne stanowią zawsze odrębne przestępstwo (Marek 2006, 216). Na podstawie tego poglądu można przyjąć, że brak jest podstaw do uznania czynów polegających na wystawieniu pustych faktur jako czynów współukaranych uprzednich do czynów polegających na doprowadzeniu do wyłudzenia podatku VAT.

Wracając do sprawy rozważań dotyczących pustych faktur, trzeba podkreślić, że jeżeli wszystkie podmioty uczestniczące w obrocie nie dokonują

${ }^{15}$ Post. SN z dnia 1 marca 2004 r., V KK 248/03, OSNKW 2004, nr 5, poz. 51 wraz z aprobującą glosą (Górniok 2004, 688).

${ }^{16}$ Uchw. SN z dnia 24 stycznia 2013 r., I KZP 19/12, LEX nr 1252697. Podobnie post. SN z dnia 24 stycznia 2013 r., I KZP 21/12, LEX nr 1252699.

${ }^{17}$ Uchw. SN z dnia 24 stycznia 2013 r., I KZP 19/12, LEX nr 1252697. 
w rzeczywistości obrotu towarem, a wystawiają puste faktury, to nawet w przypadku dokonania odliczenia podatku VAT można wywodzić, że brak jest podstaw do uznania, iż doszło do narażenia należności publicznoprawnej, ponieważ co do zasady taka należność nie istniała, a także jeżeli podmiot dokonał pomniejszenia należności, to nie ma to znaczenia, ponieważ podatek od towarów i usług nie był w żadnym zakresie należny. To samo trzeba odnieść do wystawców pustych faktur, ponieważ, opierając się na poglądzie wyrażonym w doktrynie, można przyjąć, że ustawodawca w art. 108 ustawy o podatku od towarów i usług wskazał na zapłatę sankcji, a nie podatku. Trzeba stwierdzić, że powyższe kwalifikacje prawne mają zastosowanie tylko do tych sytuacji, w których okoliczności wskazane w pustych fakturach są istotne z punktu widzenia zawartych w fakturach danych, mających wpływ na obowiązek podatkowy.

Należy wskazać, że stan prawny uległ zmianie, gdy wprowadzone zostały do Kodeksu karnego nowe przepisy, tj. art. 270a oraz art. 271a. Zgodnie z tym pierwszym karalne jest podrobienie faktury w zakresie okoliczności faktycznych, mogących mieć znaczenie dla określonej wysokości należności publicznoprawnej, jej zwrotu albo zwrotu innej należności o charakterze podatkowym. $\mathrm{Z}$ uwagi na zbyt krótki czas obowiązywania wymienionego przepisu brak jest orzecznictwa sądowego w zakresie wykładni znamion tego czynu. W doktrynie pojawił się pogląd, że art. 270a k.k. ma zastosowanie do faktur uznanych za puste, na podstawie art. 108 u.p.t.u. (Modzelewski 2017, 4-10). Budzi wątpliwości pogląd Krzysztofa Radzikowskiego, który wskazał, że ,art. 270a k.k. nie uzależnia kryminalizacji od kwoty wykazanej na podrobionej (przerobionej) fakturze" (Radzikowski 2017, 34-46). Jeżeli kwota wykazana na podrobionej lub przerobionej fakturze nie ma znaczenia, to nie zostaje wypełnione znamię „okoliczności faktycznych mogących mieć znacznie dla określenia wysokości należności publicznoprawnej lub jej zwrotu albo zwrotu innej należności o charakterze podatkowym”. Ponadto nie wiadomo, jak interpretować znamię „mogących mieć znaczenie". Określenia takiego nie używa ustawodawca w art. 271 $\S 1$ k.k., gdzie chodzi o poświadczenie co do okoliczności mającej znaczenie prawne, czyli przesądzenia o znaczeniu prawnym okoliczności. Z jednej strony przy takim podejściu, na gruncie Kodeksu karnego, do wykładni znamion czynu zabronionego może dojść do uznania, że czyn stanowi przestępstwo z surowym zagrożeniem karami, a z drugiej strony w obrocie prawnym może dojść do przyjęcia stanowiska, że należność publicznoprawna nie istnieje. Dochodzi wówczas do sprzeczności pomiędzy bezprawnością w rozumieniu ,podatkowym” a bezprawnością $\mathrm{w}$ prawie karnym.

Natomiast na podstawie drugiego z wymienionych przepisów, tj. art. 271a k.k., karalne jest wystawienie faktury lub faktur, w których poświadczona jest nieprawda co do okoliczności faktycznych, mogących mieć znacznie dla określenia wysokości należności publicznoprawnej lub jej zwrotu albo zwrotu innej należności o charakterze podatkowym lub użycie takiej faktury lub faktur. Trzeba 
zauważyć, że w ramach wykładni znamion tego czynu wyrażony został w uzasadnieniu do projektu ustawy pogląd, że

\begin{abstract}
podstawowym założeniem konstrukcji [...] art. 271a k.k. jest powiązanie karalności tego przestępstwa z ogólną wartością kwoty należności ogółem, którą zawiera faktura lub faktury, nie zaś z kwotą wartości uszczuplenia należności publicznoprawnej, która jest zamierzonym celem takiego przestępnego działania. Zabieg ten ma uprościć i zracjonalizować dowodzenie znamion tego czynu zabronionego, zwłaszcza poprzez rezygnację z konieczności korzystania w postępowaniu przygotowawczym z wyników postępowania podatkowego, mającego na celu ustalenie kwoty uszczuplenia (Mozgawa 2017, 842-843).
\end{abstract}

Trzeba podkreślić, iż nie jest możliwe określanie znamion czynu zabronionego w sposób, który ma być formą ,uproszczenia oraz zracjonalizowania procesu dowodzenia". Sfera prawa karnego materialnego jest odrębna od płaszczyzny procedury karnej. Ponadto niejasne sformułowanie znamion czynu zabronionego może być sprzeczne z art. $1 \S 1$ k.k. Zasada lex certa, która dotyczy wymogu jasnego, przewidywalnego wskazania znamion czynu zabronionego, w żadnym zakresie nie odnosi się do procedury karnej dotyczącej wykazania (udowodnienia) znamion czynu zabronionego. Są to po prostu dwie odrębne sfery prawa. Trzeba także podkreślić, że przy tak wysokim zagrożeniu ustawowym, a nawet w niektórych wypadkach od 3 lat pozbawienia wolności, czyli zbrodni, znamiona czynu zabronionego winny być jasno określone, z wykluczeniem potencjalności znaczenia $\mathrm{w}$ zakresie określenia wysokości należności publicznoprawnej - jako znamienia czynu zabronionego. W obu wypadkach znaczenie ma udzielenie odpowiedzi na pytanie, czy wskazanie okoliczności charakterystycznych dla pustej faktury uzasadnia przyjęcie kwalifikacji na podstawie jednego z wymienionych przepisów. Nie ma większych wątpliwości, jeśli chodzi o pustą fakturę, która posłużyła nabywcy towaru lub usługi do odliczenia wskazanej w niej kwoty podatku VAT, przy zastrzeżeniu, że w pozostałym zakresie obrót miał miejsce. Jeżeli natomiast obrót towarem jest w całości fikcyjny, to problematyczne staje się uznanie, że okoliczności dotyczące nieistniejącego obrotu mają wpływ na wysokość podatku, skoro jego podstawą jest obrót, a takowego nie było i podatek w ogóle nie był należny. Wówczas wątpliwe jest przypisanie popełnienia zarówno przestępstw godzących w wiarygodność dokumentu, skoro podane okoliczności nie mogły mieć znaczenia dla należności publicznoprawnej, jak i przestępstw skutkowych z Kodeksu karnego skarbowego. Pozostaje więc dla wystawcy takiej faktury tylko sankcja pozakarna, czyli art. 108 ustawy o podatku od towarów i usług, oczywiście przy przyjęciu tezy, że chodzi o sankcję quasi-podatkową.

Trzeba także zaznaczyć, że konieczne jest na poziomie określania wysokości należności publicznoprawnej wykazanie świadomego uczestniczenia w karuzeli VAT zarówno u podmiotu nabywającego towar i odliczającego podatek wykazany na otrzymanej fakturze, jak i u wystawcy faktury, co nie zawsze jest proste, szczególnie wtedy, gdy obrót towarem odbywa się tylko w części, a w „łańcuchu” mogą uczestniczyć podmioty gospodarcze, które przeprowadzają rzeczywiste operacje 
gospodarcze, a trzeba także uwzględnić to, że mają ograniczone możliwości czynienia ustaleń.

$\mathrm{Z}$ uwagi na krótki czas obowiązywania przepisów art. 270a oraz art. 271a k.k. brak jest orzecznictwa sądowego w tym zakresie. Jedynie w doktrynie wyrażony został przez Agnieszkę Liszewską pogląd, że zachowania opisane w zespole znamion czynu zabronionego stypizowanego w art. 271a $\S 1$ k.k. powinny być zakwalifikowane tylko na podstawie tego właśnie przepisu i nie znajduje do nich zastosowanie art. $62 \S 2$ k.k.s. (Liszewska 2017, 17-23). W tym miejscu należy tylko zauważyć, iż wprowadzone przepisy art. 270a oraz 271a k.k. umieszczone zostały w rozdziale, który dotyczy przestępstw przeciwko wiarygodności dokumentów, a w swoich znamionach zawierają podejmowanie czynności sprawczych w zakresie okoliczności faktycznych, mogących mieć znaczenie dla określenia wysokości należności publicznoprawnej lub jej zwrotu albo zwrotu innej należności o charakterze podatkowym. Natomiast art. 62 k.k.s. umieszczony został w rozdziale 6 , dotyczącym przestępstw przeciwko obowiązkom podatkowym i rozliczeniom z tytułu dotacji lub subwencji.

Kolejną kwestią jest podniesiony już problem uczestnictwa w karuzeli VAT jako formy uczestnictwa $\mathrm{w}$ „,cudzym przestępstwie” $\mathrm{w}$ tych przypadkach, kiedy z uwagi na fikcyjny w całości obrót towarem przez jeden podmiot, do którego nie zostanie wydana decyzja określająca wysokość należności publicznoprawnej, a przyjęty zostanie pogląd, że sankcja przewidziana w art. 108 u.p.t.u. nie jest podatkiem. Chodzi o konstrukcję współsprawstwa, w której nie ma współdziałania rozumianego jako wypełnienie znamion czynu zabronionego, nawet w części. Wymieniona koncepcja oparta jest na podziale czynności, których końcowym efektem ma być popełnienie zamierzonego przestępstwa, przy czym współsprawcą jest także ta osoba, która wprawdzie nie realizuje znamienia czasownikowego danego przestępstwa, ale czynności, które podejmuje stanowią istotny wkład w popełnienie tego przestępstwa. Pojęcie współsprawstwa oparte jest na świadomości wnoszenia istotnego wkładu przez każdego ze współsprawców. Koncepcja ta została przyjęta w doktrynie między innymi przez Andrzeja Zolla ${ }^{18}$, Andrzeja Wąska $^{19}$, Leona Tyszkiewicza, Kazimierza Buchałę, Igora Andrejewa (Tyszkiewicz

${ }^{18}$ Zoll (1998, 172-173) twierdzi, że „należy odrzucić formalno-obiektywne ujęcie [współsprawstwa - przyp. K.P.] przyjmując, że współsprawcą jest zarówno ten, kto realizuje współdziałając z drugą osobą, samodzielnie część znamion czasownikowych czynu zabronionego, jak i ten kto wprawdzie w wyniku podziału ról nie realizuje żadnego znamienia czasownikowego, ale wykonana przez niego czynność ma istotne znaczenie dla popełnienia tego czynu".

${ }^{19}$ Wąsek (1977, 116-117) wskazuje, że „współsprawcą będzie osoba, która w porozumieniu z inną realizuje całość lub część ustawowych znamion przestępstwa. Będzie nią także i ta osoba, która wprawdzie nie wykonuje czynności odpowiadającej znamieniu czasownikowemu danego przestępstwa, ale której zachowanie się uzgodnione ze wspólnikiem (lub wspólnikami) stanowi istotny wkład w realizację wspólnego przestępnego zamachu. O tym, że rola danej osoby jest istotna świadczy zwykle hipotetyczne przyjęcie, że przez odstąpienie tej osoby od działania przestępstwo w ogóle nie zostałoby dokonane albo byłoby dokonane w inny sposób". 
1977, 18; 1990, 53-55; Buchała 1980, 419; Andrejew 1988a, 28; Andrejew 1988b, 203-204; Dębski 2013, 921-922). Trzeba jednak zaznaczyć, że inne stanowisko w tym zakresie zaprezentował Władysław Wolter, który stwierdził, że po stronie osoby nie wypełniającej żadnego elementu znamienia czynnościowego nie dochodzi do wypełnienia znamion współsprawstwa (Wolter 1973, 298).

Również orzecznictwo sądowe już od początku lat 70. ubiegłego wieku opowiedziało się za konstrukcją współsprawstwa koniecznego ${ }^{20}$.

Podniesiona została także kwestia świadomości wartości mienia, jaką można przypisać współsprawcom ${ }^{21}$. Orzeczenia te mają znaczenie w konstrukcji współsprawstwa przy wystawianiu pustych faktur i wyłudzaniu podatku VAT w zakresie wiedzy co do wartości kwoty dla całej karuzeli VAT, przy założeniu, że cały obrót jest fikcyjny i zmierza do wyłudzenia zwrotu podatku. Odnosząc ich treść do współsprawstwa w przestępstwach tzw. karuzeli podatkowej, trzeba podkreślić, iż wymagane jest wykazanie porozumienia oraz współdziałania poszczególnych uczestników tego procederu, co nie zawsze ma miejsce. W karuzeli VAT mogą uczestniczyć podmioty gospodarcze, które nie mają świadomości jej istnienia i wykorzystania ich dla wiarygodności transakcji w jej ramach. Ponadto współsprawstwo wymaga wykazania wiedzy co do kwoty uszczuplenia dla całej karuzeli VAT, a to nie zawsze jest oczywiste, ponieważ wysokość uszczuplenia wynika z wielkości żądanej kwoty do zwrotu, przy założeniu fikcyjności faktur

${ }^{20}$ Wyr. SN z dnia 22 listopada 1971 r., Rw 1202/71, OSNKW 1972, nr 3, poz. 54, gdzie sąd wskazał, że ,[i] stotą współsprawstwa w ujęciu art. 16 k.k. jest oparte na porozumieniu współdziałanie dwóch lub więcej osób, z których każda obejmuje swym zamiarem realizację całości znamion określonego czynu przestępczego. To porozumienie się jest tym szczególnym elementem podmiotowym, który zespalając zachowanie się poszczególnych osób, pozwala przypisać każdej z nich również i tę akcję sprawczą, którą przedsięwzięła inna osoba współdziałająca w popełnieniu przestępstwa" [art. 16 Kodeksu karnego z 1969 r. - sprawstwo i współsprawstwo], podobne stanowisko wyrażone zostało w orzecznictwie sądów apelacyjnych, przykładowo w wyr. SA w Katowicach z dnia 26 marca 1998 r., AKa 41/98 (zob. „Orzecznictwo Sądu Najwyższego, Sądów Apelacyjnych, Naczelnego Sądu Administracyjnego i Trybunału Konstytucyjnego". 1998. Prokuratura i Prawo [dodatek] 11-12: 26); w wyr. SA w Łodzi z dnia 14 października 1998 r., II AKa 129/98 (zob. „Orzecznictwo Sądu Najwyższego, Sądów Apelacyjnych, Naczelnego Sądu Administracyjnego i Trybunału Konstytucyjnego". 2000. Prokuratura i Prawo Prokuratura i Prawo [dodatek] 5: 18); wyr. SA w Łodzi z dnia 23 listopada 2000 r., II AKa 169/00 (zob. „Orzecznictwo Sądu Najwyższego, Sądów Apelacyjnych, Naczelnego Sądu Administracyjnego i Trybunału Konstytucyjnego”. 2001. Prokuratura i Prawo [dodatek] 6: 13).

${ }^{21}$ Wyr. SN z dnia 25 sierpnia 1987 r., III KR 288/87, OSNPG 1988, nr 7, poz. 68, w którym sąd stwierdził, że „,[o]skarżony brał udział we włamaniu do sklepu WCH, stojąc na czatach w punkcie obserwacyjnym, ale kiedy współoskarżeni po dokonaniu włamania, polecili mu przeniesienie łupu odmówił pomocy w tym zakresie i opuścił miejsce włamania. Oskarżony nie wiedział co znajduje się w workach z łupami. Powyższe okoliczności wskazują, że oskarżony nie znał wartości skradzionych rzeczy, a w szczególności, że mienie to posiada wartość powyżej 300 tys. zł i wobec tego brak podstaw do przypisania mu czynu z art. 201 k.k. natomiast jego czyn wyczerpuje znamiona przestępstwa z art. 208 k.k.” [art. 201 Kodeksu karnego z 1969 r. - zagarnięcie mienia znacznej wartości, art. 208 Kodeksu karnego z 1969 r. - kradzież z włamaniem]. 
i podjęcia czynności pozorujących zwrot podatku w związku z wewnątrzwspólnotową dostawa towaru lub usługi przez jednego z uczestników tzw. karuzeli. Wówczas to świadomość wielkości tej kwoty może być - co do zasady - przypisana tylko temu uczestnikowi karuzeli, który ubiega się o zwrot podatku. W innych przypadkach wielkość uszczuplenia wynika z przeprowadzonych kontroli u konkretnego podatnika. Stąd konstrukcja współsprawstwa oparta na istotnym wkładzie w popełnione przestępstwo, polegającym na obrocie pustymi fakturami, aby ostatecznie żądać zwrotu, napotyka na trudności na poziomie świadomości uczestniczenia w karuzeli VAT oraz świadomości wielkości kwoty oszustwa podatkowego. Te same wątpliwości dotyczą obrotu w części pustymi fakturami, a w części towarem, przy czym kwota uszczuplenia podatkowego będzie w każdym przypadku inna dla każdego podatnika, a tym samym wątpliwe będzie przypisanie sumy uszczuplonych kwot każdemu z podatników.

\section{ZAKOŃCZENIE}

Zjawisko karuzeli VAT wymaga analizy na różnych płaszczyznach. Jedną $\mathrm{z}$ nich jest ocena w kierunku wskazania, czy wystawianie pustych faktur powoduje obowiązek zapłaty podatku, czy też nie. Konsekwencje dla podmiotów zajmujących się działalnością, która skutkuje powstaniem obowiązku podatkowego - zarówno w zakresie należności publicznoprawnej, jak i karnoskarbowej oraz karnej - mogą być bardzo dotkliwe, dlatego ocena zjawiska musi odbywać się na podstawie wszystkich możliwych ustaleń stanu faktycznego, świadomości uczestniczenia w karuzeli VAT oraz oceny prawnej. Liczba podmiotów uczestniczących w obrocie, zakres tego obrotu, braki w dokumentach łączą się z długotrwałym postępowaniem zmierzającym do ustalenia istnienia należności publicznoprawnej oraz ewentualnie uznania zachowań za wypełniające znamiona przestępstwa karnego oraz przestępstwa karnoskarbowego w ramach tzw. karuzeli podatkowej.

Nie uprawnia to jednak do stosowania uproszczeń, szczególnie w zakresie przepisów Kodeksu karnego oraz Kodeksu karnego skarbowego.

\section{BIBLIOGRAFIA}

Andrejew, Igor. 1970. Polskie prawo karne w zarysie. Warszawa: Państwowe Wydawnictwo Naukowe.

Andrejew, Igor. 1988a. Kodeks karny - krótki komentarz dla studiujących. Warszawa: Państwowe Wydawnictwo Naukowe.

Andrejew, Igor. 1988b. Podstawowe pojęcia nauki o przestępstwie. Warszawa: Państwowe Wydawnictwo Naukowe.

Buchała, Kazimierz. 1980. Prawo karne materialne. Warszawa: Państwowe Wydawnictwo Naukowe. 
Buchała, Kazimierz, Andrzej Zoll. 1998. Kodeks karny. Część ogólna. Kantor Wydawniczy Zakamycze.

Dębski, Ryszard (red.). 2013. Nauka o przestępstwie. Zasady odpowiedzialności. Warszawa: Wydawnictwo C.H. Beck.

Duda, Jacek. 2013. „Glosa do uchwały SN z dnia 24 stycznia 2013 r., I KZP 19/12”. Czasopismo Prawa Karnego i Nauk Penalnych 1: 123-133.

Duży, Jerzy. 2013. „Glosa do wyroku Sądu Apelacyjnego w Katowicach z dnia 3 lutego 2011 roku. II AKa 476/10". Prokuratura i Prawo 5: 176-182.

Górniok, Oktawia. 2004. „Glosa do postanowienia Sądu Najwyższego z dnia 1 marca 2004 r., V KK 248/03". Orzecznictwo Sądów Polskich 12: 683-689.

Hermann, Mikołaj, Sebastian Sykuna (red.). 2016. Wykładnia prawa. Tradycja i perspektywy. Warszawa: Wydawnictwo C.H. Beck.

Kanarek, Janusz. 2013. „Glosa do uchwały SN z dnia 24 stycznia 2013 r., I KZP 19/12”. Palestra 7-8: 173-177.

Kardas, Piotr. 2007. „Karnoprawne aspekty posłużenia się fakturą nierzetelną”. Prokuratura i Prawo 2: 5-27.

Kołodziejski, Paweł. 2015. „Skuteczność ścigania przestępczości skarbowej a zmiany systemowe”. Prokuratura i Prawo 3: 86-105.

Kubacki, Ryszard, Adam Bartosiewicz. 2005. Kodeks karny skarbowy. Przestęstwa i wykroczenia podatkowe oraz dewizowe. Warszawa: Wydawnictwo C.H. Beck.

Liszewska, Agnieszka. 2017. „Odpowiedzialność karna za wystawienie faktury w sposób nierzetelny lub używanie takiej faktury po nowelizacji”. Przegląd Podatkowy 9: 17-23.

Marek, Andrzej. 2006. Prawo karne. Warszawa: Wydawnictwo C.H. Beck.

Modzelewski, Witold. 2017. „Wystawianie i ewidencjonowanie faktur VAT w świetle nowych przepisów Kodeksu karnego". Doradztwo Podatkowe 2: 4-10.

Mozgawa, Marek. 2017. Kodeks karny. Komentarz. Warszawa: Wydawnictwo Wolters Kluwer.

Oczkowski, Tomasz. 2009. „Problematyka prawnokarnej oceny wyłudzenia podatku VAT”. Prokuratura i Prawo 7-8: 82-101.

Ożóg, Irena (red.). 2017. Przestępstwa karuzelowe i inne oszustwa w VAT. Warszawa: Wydawnictwo Wolters Kluwer Polska.

Radzikowski, Krzysztof. 2017. „Nowelizacja kodeksu karnego i kodeksu karnego skarbowego w zakresie tzw. przestępstw fakturowych". Przeglad Podatkowy 3: 34-46.

Tyszkiewicz, Leon. 1977. „Istota współsprawstwa na tle kodeksu karnego”. Problemy Prawa Karnego 3: 13-24.

Tyszkiewicz, Leon. 1990. „Problemy współdziałania przestępnego de lege ferenda”. Palestra 34 (1): $50-61$.

Wąsek, Andrzej. 1977. Wspótsprawstwo w polskim prawie karnym. Warszawa: Wydawnictwo Prawnicze.

Wilk, Leszek. 2013. „Glosa do uchwały SN z dnia 24 stycznia 2013 r., I KZP 19/12. Prawo karne skarbowe - idealny zbieg przestępstw”. Orzecznictwo Sądów Polskich 7-8: 602-609.

Wolter, Władysław. 1973. Nauka o przestępstwie. Warszawa: Państwowe Wydawnictwo Naukowe.

\section{Akty prawne}

Dyrektywa nr 2006/112/WE Rady Unii Europejskiej z dnia 28 listopada 2006 r. w sprawie wspólnego systemu podatku od wartości dodanej (Dz.Urz. UE L z 2006 r. Nr 347/1).

Szósta dyrektywa Rady z dnia 17 maja 1977 r. w sprawie harmonizacji ustawodawstwa Państw Członkowskich w odniesieniu do podatków obrotowych - wspólny system podatku od wartości dodanej: ujednolicenia podstaw wymiary podatku (77/388/EWG) (Dz.Urz. UE L z 1977 r. $\mathrm{Nr} 145.1)$. 
Ustawa z dnia 6 czerwca 1997 r. - Kodeks karny (Dz.U. z 1997 r. Nr 88, poz. 553 ze zm.).

Ustawa z dnia 10 września 1999 r. - Kodeks karny skarbowy (tekst jedn. Dz.U. z 2017 r., poz. 2226 ze zm.).

Ustawa z dnia 11 marca 2004 r. o podatku od towarów i usług (tekst jedn. Dz.U. z 2017 r., poz. 1221 ze zm.).

Ustawa z dnia 10 lutego 2017 r. o zmianie ustawy - Kodeks karny oraz niektórych innych ustaw (Dz.U. z 2017 r., poz. 244).

\section{Orzecznictwo}

Postanowienie SN z dnia 1 marca 2004 r., V KK 248/03, OSNKW 2004, nr 5, poz. 51.

Postanowienie SN z dnia 24 stycznia 2013 r., I KZP 21/12, LEX nr 1252699.

Postanowienie SN z dnia 15 listopada 2013 r., II KK 295/13, LEX nr 1391781.

Uchwała SN z dnia 24 stycznia 2013 r., I KZP 19/12, LEX nr 1252697.

Wyrok NSA w Warszawie z dnia 30 lipca 2009 r., I FSK 866/08, LEX nr 552188.

Wyrok NSA w Warszawie z dnia 4 grudnia 2009 r., I FSK 1859/08, LEX nr 615971.

Wyrok NSA w Warszawie z dnia 27 września 2011 r., I FSK 1403/10, LEX nr 1068161.

Wyrok NSA w Warszawie z dnia 2 października 2012 r., I FSK 2017/11, LEX nr 1233050.

Wyrok NSA w Warszawie z dnia 26 listopada 2014 r., I FSK 1537/13, LEX nr 1658030.

Wyrok NSA w Warszawie z dnia 31 maja 2017 r., I FSK 1824/15, LEX nr 2314508.

Wyrok SA w Katowicach z dnia 26 marca 1998 r., AKa 41/98, „Orzecznictwo Sądu Najwyższego,

Sądów Apelacyjnych, Naczelnego Sądu Administracyjnego i Trybunału Konstytucyjnego”. 1998. Prokuratura i Prawo [dodatek] 11-12: 26.

Wyrok SA w Katowicach z dnia 25 maja 2012 r., II AKa 97/12, LEX nr 1220220.

Wyrok SA w Katowicach z dnia 16 stycznia 2014 r., II AKa 195/13, LEX nr 1422354.

Wyrok SA w Katowicach z dnia 8 sierpnia 2014 r., II AKa 200/14, LEX nr 1500762.

Wyrok SA w Łodzi z dnia 14 października 1998 r., II AKa 129/98, „Orzecznictwo Sądu Najwyższego, Sądów Apelacyjnych, Naczelnego Sądu Administracyjnego i Trybunału Konstytucyjnego”. 2000. Prokuratura i Prawo [dodatek] 5: 18.

Wyrok SA w Łodzi z dnia 23 listopada 2000 r., II AKa 169/00, „Orzecznictwo Sądu Najwyższego, Sądów Apelacyjnych, Naczelnego Sądu Administracyjnego i Trybunału Konstytucyjnego". 2001. Prokuratura i Prawo Prokuratura i Prawo [dodatek] 6: 13.

Wyrok SA w Szczecinie z dnia 12 maja 2016 r., II AKa 4/16, LEX nr 2093798.

Wyrok SN z dnia 22 listopada 1971 r., Rw 1202/71, OSNKW 1972, nr 3, poz. 54.

Wyrok SN z dnia 25 sierpnia 1987 r., III KR 288/87, OSNPG 1988, nr 7, poz. 68.

Wyrok SN z dnia 30 września 2003 r., I KZP 22/03, OSNKW 2003, nr 9-10, poz. 75.

Wyrok SN z dnia 19 marca 2008 r., II KK 347/07, LEX nr 388503.

Wyrok SN z dnia 12 sierpnia 2008 r., V KK 76/08, LEX nr 449041.

Wyrok SN z dnia 22 października 2009 r., IV KK 433/08, OSNwSK 2009, nr 1, poz. 2115.

Wyrok SN z dnia 31 marca 2015 r., I KZP 28/14, OSNKW 2015, nr 5, poz. 40.

Wyrok TSUE z dnia 13 grudnia 1989 r., C-342/87, LEX nr 84293.

Wyrok TSUE z dnia 6 listopada 2003 r., C-78/02, LEX nr 174079.

Wyrok TSUE z dnia 6 lipca 2006 r. w sprawach połączonych C-439/04 Axel Kittel v. Państwo Belgijskie oraz C-440/04 Państwo Belgijskie v. Recolta Recycling SPRL. http://www.eur-lex. europa.eu [dostęp 3.06.2018].

Wyrok TSUE z dnia 18 czerwca 2009 r., C-566/07, LEX nr 498853.

Wyrok TSUE z dnia 21 czerwca 2012 r., C-80/11, LEX nr 1165797.

Wyrok TSUE z dnia 6 grudnia 2012 r., C-285/11, LEX nr 1229752.

Wyrok TSUE z dnia 31 stycznia 2013 r., C-642/11, LEX nr 1258555.

Wyrok TSUE z dnia 13 lutego 2014 r., C-18/13, LEX nr 1424765. 
Wyrok TSUE z dnia 22 października 2015 r., C-277/14, LEX nr 1814891.

Wyrok WSA w Bydgoszczy z dnia 6 czerwca 2011 r., I SA/Bd 118/11, LEX nr 990375.

Wyrok WSA w Bydgoszczy z dnia 11 lipca 2017 r., I SA/Bd 444/17, LEX nr 2326299.

Wyrok WSA w Gliwicach z dnia 11 czerwca 2014 r., III SA/G1 70/14, LEX nr 150830.

Wyrok WSA w Warszawie z dnia 10 maja 2010 r., III SA/Wa 384/10, LEX nr 603708.

Wyrok WSA w Warszawie z dnia 19 stycznia 2017 r., III SA/Wa 3318/15, LEX nr 2267959.

Wyrok WSA we Wrocławiu z dnia 26 sierpnia 2008 r., I SA/Wr 143/08, LEX nr 485315.

Wyrok WSA we Wrocławiu z dnia 25 kwietnia 2017 r., I SA/Wr 1373/16, LEX nr 2315820.

\title{
Krystyna Patora
}

\section{THE CRIME OF ISSUING "EMPTY" VAT INVOICES}

\begin{abstract}
The subject of this article was issuing 'empty' invoices, including first and foremost explanation what should be understood under this concept in the jurisprudence of Polish Courts as well as the Tribunal of Justice. Moreover, the subject of consideration covered tax effects concerning the possibility of deducting the sum indicated on the invoice by the recipient of the invoice as well as those for the invoice issuer resulting from article 108 of the act of tax on goods and services. Due to the fact that the legal qualification of these events is not uniformly recognized in jurisprudence and in the doctrine, it has become indispensable to present views in this respect.
\end{abstract}

Keywords: value added tax (VAT), input tax (on purchase), tax due (on sale), 'empty' invoice. 